\title{
In With The Old, Out With The New: Green Marketing And The Used Merchandise Sector
}

Dr. Kelly La Venture, Bemidji State University, USA

Dr. Chantal Norrgard, Independent Scholar, Vancouver, BC, Canada

\begin{abstract}
This study explores the emergence of the used merchandise sector and its implications for green marketing. We demonstrate that although few consumers purchase green products based on environmental concerns, consumers who shop for used merchandise do so with these issues in mind. Examining consumer blogs, we uncover the relationship between the environmental movement and the growth of the used merchandise sector. Green marketing has failed to account for this shift, because it focuses on the consumption of green products rather than consumption reduction facilitated by the used merchandise sector and re-use market. To make a difference, green marketing must change emphasis from consumption to consumption reduction.
\end{abstract}

Keywords: Green Marketing; Consumption; Consumption Reduction; Marketing; Used Merchandise Sector; Consumer Behavior; Consumer Blogs; Environmental Movement

\section{INTRODUCTION}

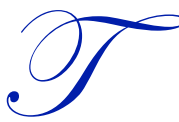

oday, a range of green products and technologies are available to consumers as businesses capitalize on consumer concerns about environmental issues and market their products and services as green. However, a number of polls and studies have suggested that only a small fraction of consumers purchase green products and services. In a 2014 Gallup poll, $42 \%$ of respondents were sympathetic to environmental concerns, but not active in the environmental movement or purchasing green products. While those self-reporting as active participants has fluctuated with a low of $14 \%(2003 ; 2004 ; 2006)$ and high of $22 \%(2008)$ unsympathetic has risen from 5\% to $10 \%$ (2000 to 2014) and sympathetic, but not active has dropped from $55 \%$ to $42 \%$ (2000 to 2014$)$. As evidenced in Table 1, there has not been a shift in people's actions in relation to the environmental movement. Based on this data, marketing scholars have argued that the environmental movement has not significantly impacted consumer behavior or purchasing habits and that green marketing has been ineffective. 
Table 1. Gallup Environmental Poll

\begin{tabular}{|c|c|c|c|c|c|}
\hline \multicolumn{6}{|c|}{$\begin{array}{l}\text { Thinking about the environmental movement, do you think of yourself as - an active participant in the environmental movement, sympathet } \\
\text { towards the movement, but not active, neutral, or unsympathetic towards the movement? }\end{array}$} \\
\hline & Active participant & $\begin{array}{l}\text { Sympathetic, but } \\
\text { not active }\end{array}$ & Neutral & Unsympathetic & No opinion \\
\hline 2014 Mar 6-9 & $18 \%$ & $42 \%$ & $26 \%$ & $10 \%$ & $3 \%$ \\
\hline 2013 Mar 7-10 & $17 \%$ & $42 \%$ & $29 \%$ & $10 \%$ & $2 \%$ \\
\hline 2012 Mar 8-11 & $17 \%$ & $40 \%$ & $30 \%$ & $11 \%$ & $2 \%$ \\
\hline 2011 Mar 3-6 & $20 \%$ & $42 \%$ & $27 \%$ & $9 \%$ & $2 \%$ \\
\hline 2010 Mar 4-7 & $19 \%$ & $42 \%$ & $28 \%$ & $10 \%$ & $1 \%$ \\
\hline 2008 Mar 6-9 & $22 \%$ & $47 \%$ & $25 \%$ & $6 \%$ & $1 \%$ \\
\hline 2007 Mar 11-14 & $21 \%$ & $49 \%$ & $23 \%$ & $5 \%$ & $2 \%$ \\
\hline 2006 Mar $13-16$ & $14 \%$ & $48 \%$ & $29 \%$ & $7 \%$ & $2 \%$ \\
\hline 2005 Mar 7-10 & $16 \%$ & $49 \%$ & $28 \%$ & $5 \%$ & $2 \%$ \\
\hline 2004 Mar 8-11 & $14 \%$ & $47 \%$ & $30 \%$ & $8 \%$ & $1 \%$ \\
\hline 2003 Mar 3-5 & $14 \%$ & $47 \%$ & $32 \%$ & $6 \%$ & $1 \%$ \\
\hline 2002 Mar 4-7 & $19 \%$ & $51 \%$ & $24 \%$ & $5 \%$ & $1 \%$ \\
\hline 2001 Mar 5-7 & $18 \%$ & $50 \%$ & $25 \%$ & $5 \%$ & $2 \%$ \\
\hline 2000 Apr 3-9 & $16 \%$ & $55 \%$ & $23 \%$ & $5 \%$ & $1 \%$ \\
\hline
\end{tabular}

Adapted from Gallup http://www.gallup.com/poll/1615/environment.aspx

However, one area that has been largely overlooked in literature is the used merchandise sector of the retail industry, which is also referred to as the used merchandise industry. The used merchandise sector includes antique stores, resale shops, thrift shops, and consignment shops. Prices in these stores range from 60 to 75 percent below normal retail prices (First Research, 2014).

The used merchandise sector has its roots in European flea-markets, antiques stores, and charity shops that can be traced back to at least as early as the late-nineteenth century. It is difficult to pin point when these markets expanded into North America. However, they became widespread during WWII when household goods and clothing were in short-hand due to rationing (Konerding, 2010).

Although, second-hand stores have somewhat retained a negative image as "junk stores" associated with financial difficulty, they are growing in popularity and prestige. In fact, the 2014 Used Merchandise Industry Report predicts steady growth in the next decade (First Research, 2014). Moreover, television shows, like "Mad Men," Spike TV's "Thrift Hunters," and PBS's "Antique Roadshow" as well as a healthy hipster culture, and pop-songs like Macklemore's "Thrift Store" illuminate how second-hand shopping has made its way into popular culture and has become an acceptable, if not recreational activity. The growth of the used merchandise sector can be attributed to the recent recession as more people attempt to find goods they need and want for less, but it is also connected to consumer efforts to re-examine their impact on the environment.

Although literature on the used merchandise sector is slim, both qualitative and quantitative studies that have measured second-hand shoppers motivations for purchasing used items cite their concerns about the environment and sustainability as main reasons they purchase used rather than new goods (Guiot \& Roux, 2010; Lorenzen, 2012; Papaoikonomou; 2013; Sheth, Sethia \& Srinivas, 2011; Williams \& Paddock, 2003).

In this paper, we review data on the used merchandise sector, including evidence of growth, and explore the characteristics of consumer behavior linked to their concerns about the environment. We offer suggestions about why the literature on green marketing has failed to account for the role of the used merchandise sector in green consumerism and what the implications might be if this sector was taken into account in studies of green marketing.

We include evidence from blogs, sources that have been largely overlooked; in order to gain additional perspective on the motivations of consumers of used merchandise. Blogs are a new form of social media, which reflect the current pulse of culture and society. They are also autobiographical and allow us to study the values, choices, and habits of consumers. We looked at blogs from the U.S. and Canada, two countries in which the popularity of secondhand shopping is clearly growing, and we explored the perspectives of bloggers who focus on thrift store shopping. 
Although the space of this paper allows us only to examine a small sample of these blogs, we suspect that further exploration would yield more evidence to support our argument that the growth of used merchandise sector is linked to consumer efforts to adopt a green lifestyle. Further study may also reveal more about the class and gender dynamics of this market (all the bloggers we came across were middle aged working class women).

\section{THE USED MERCHANDISE SECTOR}

Used merchandise stores sell used clothing, antiques, furniture, books, and accessories. Major US companies include The Salvation Army, Savers, Winnmark, and Goodwill. According to First Research (2014), the used merchandise stores sector in the U.S. includes 18,000 stores with combined annual revenue of about $\$ 12$ billion.

Second-hand shopping is "the acquisition of second-hand objects through methods and places of exchange that are generally distinct from those for new products" (Guiot \& Roux, 2010: 336). This sector is in competition with conventional retail outlets who offer new, inexpensive merchandise in stores, and online (Guiot \& Roux, 2010). Second-hand retailers also compete with individuals selling merchandise privately or through websites, such as Craigslist or eBay and product swapping services, such as Freecycle (First Research, 2014). The rise of second-hand shopping "implies the existence of retail expectations that traditional channels cannot satisfy" (Guiot \& Roux, 2010) and second-hand retailers are adjusting to competition and finding new ways to compete. Conventional sellers use Internet Merchandise Trade to reach buyers directly (First Research, 2014).

In response to this trend, used merchandise stores have utilized web retailing and have established an online presence to reach consumers. The Buffalo Exchange and Crossroads Trading Company are two examples of online retailing in the used merchandise sector. At the Buffalo Exchange, "clothing and accessories are bought, sold and traded locally with store customers" (http://www.buffaloexchange.com). Similarly, Crossroads Trading Company "specializes in buying and selling clothing and accessories to and from the public for either cash or trade credit" (http://crossroadstrading.com/). Other web services include, http://www.atticclothes.com/,http://www.oxfam.org.uk/ shop/second-hand-clothes, and http://www.clothingexchange.com.au. Whether used goods are traded, recycled, or purchased in stores or online, there is clearly a demand for this merchandise.

While repeat customers, including collectors, bargain shoppers, wholesalers, dealers, and internet retailers, are some of the most important to used merchandise retailers (First Research, 2014), the demographics of the consumers of this sector have shifted over the past decade from those who are poverty-stricken or the die-hard collectors to average consumers (Darley \& Lim, 1999). This shift has been fueled by the changing image and techniques of used merchandise stores; they understand that the average consumer is cautious in their buying habits. Therefore, used merchandise stores are trying to provide higher quality goods. By maintaining high quality inventory, they negate the perception that used goods are low quality and inferior to new - thus attracting and retaining the average consumer. This factor combined with economic instability of the past ten years has led many consumers to purchase used items to stretch budgets and cut costs. For example, a National Retail Federation (2014) survey indicated that about $13 \%$ of back-to-school shoppers visited resale and thrift stores in 2014. "An uneven economy has kept shoppers using thrift stores as a budget-friendly way to make back-to-school purchases" (First Research, 2014).

In addition, the National Association of Resale and Thrift Shops (NARTS, 2014), a consumer research firm, found that about $16-18 \%$ of Americans shop at a thrift store during a given year and 12-15\% of Americans shop at consignment and resale shops. During the same time frame, "11.4\% of Americans shopped in factory outlet malls, $19.6 \%$ in apparel stores and $21.3 \%$ in major department stores" (NARTS, 2014). These percentages indicate the presence of a competitive re-use market. Figure 1 depicts the increase in monthly used merchandise sales as reported in the Monthly Retail Trade Survey from January 2000 to January 2014, showing that used merchandise stores have seen steady growth in sales. 
Figure 1. Used Merchandise Stores: U.S.

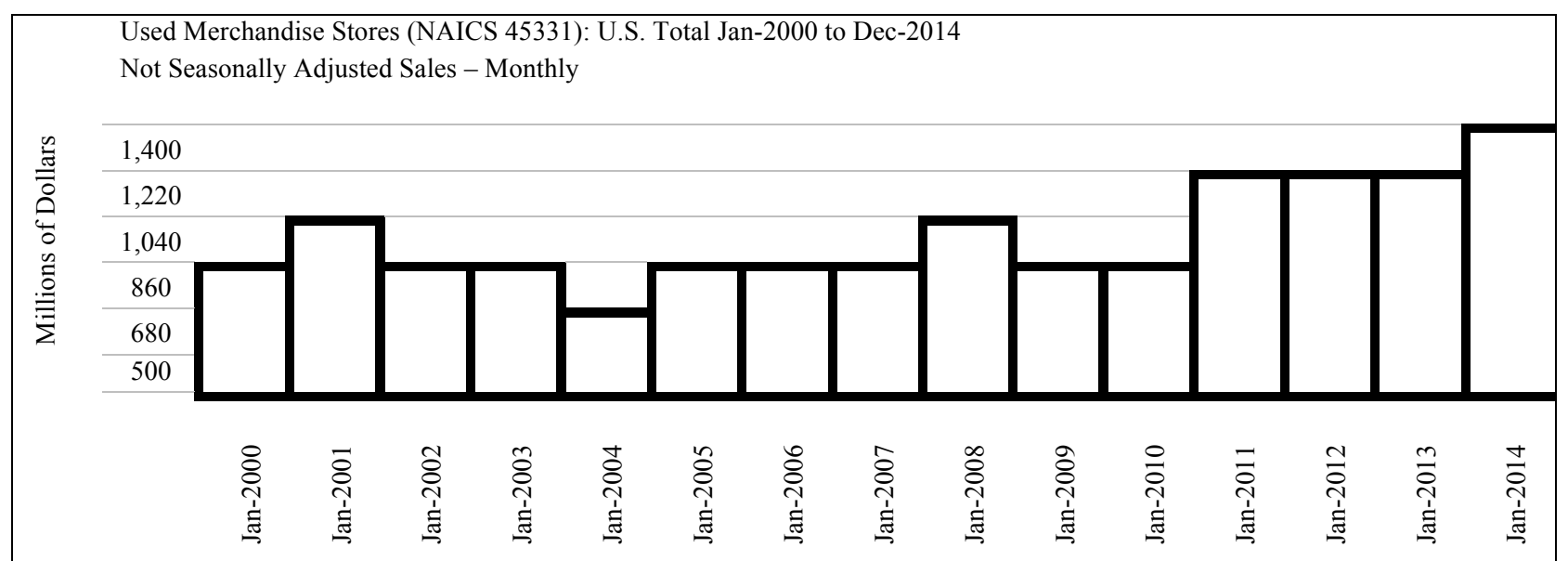

Adapted from Monthly Retail Trade and Food Services. These data are approximations and online data reveals fluctuations within these not seasonally adjusted monthly sales.

The increase in sales in this sector from 2000 to 2014 has led to the expansion of used merchandise stores. According to NARTS (2014), the number of stores has increased by more than 7 percent annually.

Similarly, data from Statistics Canada (2011) reported the used merchandise sector saw an $8.8 \%$ increase between 2010 and 2011 with the sector generating \$106.6 million in profits in 2011 - up \$74.5 million from 2002 (Figure 2).

Figure 2. Used Merchandise Stores: Canada Total 2002 to 2011

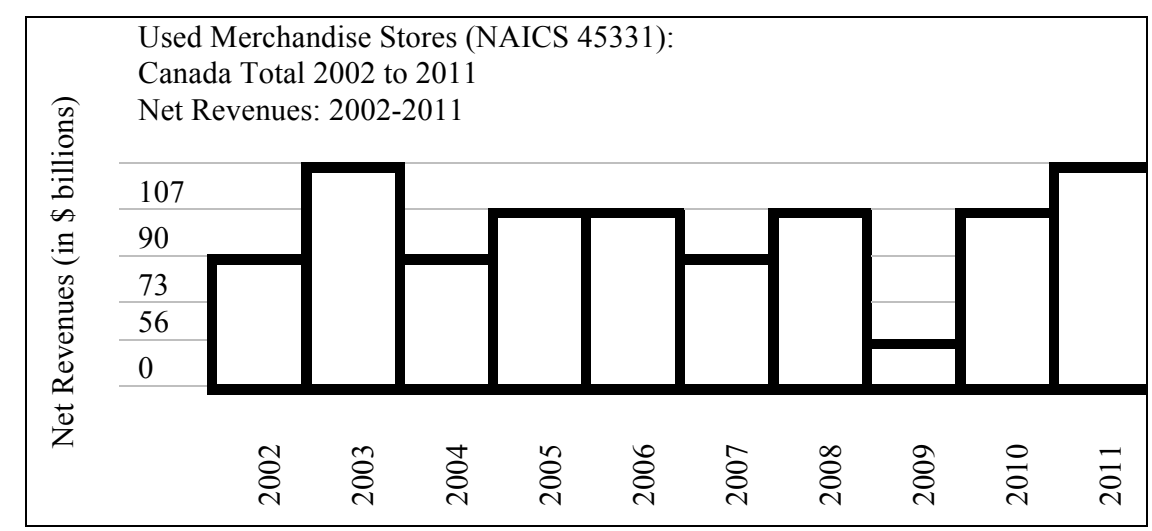

Adapted from Statistics Canada, special tabulation, unpublished data, Annual Retail Trade Survey. These data are approximations.

This evidence suggests the market for used items in North America is expanding, and the used merchandise sector is finding new ways to compete with conventional retailers through quality control and Internet retail trade. When considered with consumers' environmental motivations for shopping for used items, these findings challenge the conclusion that the Green Movement has had little impact on consumer actions.

\section{CONSUMER BEHAVIOR AND ENVIRONMENTAL CONCERNS}

Generally, economists focus on consumer behavior at a macro-level and concentrate on the behavior of the aggregate economy, whereas, researchers, who study consumer behavior focus on individual consumers at the micro-level. Consumer behavior accounts for the totality of consumers' decisions with respect to the acquisition, consumption, and disposition of goods, services, time, and ideas (Hoyer \& MacInnis, 2010). It is the set of valueseeking activities that take place as people go about addressing real needs (Free, 2010). The process involves a 
multitude of psychological events, which include assessing and making choices based on experiences, value, and culture. Guiox and Roux, wrote that, "motivations for second-hand shopping refer to the psychological and material motives that orient consumers toward second-hand products and/or channels" (2010: 357).

Consumer action in a free enterprise system constitutes shopping patterns or the choices they make when faced with a number of options. Within a free enterprise system, individuals are allowed to participate freely in the market (Tucker \& Ryan, 2013) and have an abundance of choices. Consumers can purchase new, used, recycled and refurbished merchandise in a variety of retail outlets. Some of their choices include shopping online, at 'big-box stores', 'shopping small', and making purchases at used merchandise stores. When a consumer is motivated by a need (such as to eat) the process begins when the consumer sets out to find a desirable way to fill this need (in this case, purchasing food to eat). Moreover, shopping patterns shift based on the consumers' worldview and their sensitivity to issues, such as the state of the environment.

Marketing research into the impacts of environment issues began nearly three decades ago. In 1987, the Brundtland Report, 'Our Common Future' (United Nations, 1987), demonstrated "the unsustainable nature of existing patterns of development, production and consumption" (Peattie \& Peattie, 2009: 260) and imparted the concept of sustainability into the mainstream of business and political thought (Peattie \& Peattie, 2009). Researchers believed that consumer concerns about environmental and social issues would influence consumer behavior (Vandermerwe \& Oliff, 1990; Worcester, 1993) and lead consumers and organizations to act. In the 1990's, when the concept of sustainability became mainstream researchers in the social sciences and marketing began to focus more on environmental issues (Alwitt \& Pitts, 1996; Berger, 1997; Berger \& Corbin, 1992; Pieters, Bijmolt, van Raaij, de Kruijk, 1998; Shrum, McCarty \& Lowrey, 1995). As consumers became "aware of issues related to the fragile state of the environment, they placed greater importance on environmentally friendly products" (Gleim, Smith, Andrews, Cronin, 2013: 44). Environmental issues attracted consumer attention and more consumers placed an emphasis on green energy consumption (Awan, Sarwar \& Raza, 2011), green shopping (Thøgersen, 2011) and green behavior (Paco, Alves, Shiel \& Leal Filho, 2009).

Yet, most consumers do not base their purchasing decisions solely on their attitudes toward the environment. Cross (2000) has argued that reducing consumption is difficult because our personal identities are formed around goods and products. While we agree with Cross (2000), we also suggest that consumer beliefs about consumption are shifting. While most green consumers are not considered "active participants" in the environmental movement (Figure 1), there are many whose patterns fall under the category of green consumption. The characteristics of these consumers suggest they are living a green lifestyle and less tied to the idea that what they have and what they own is tied to who they are.

Consumers, whose patterns fall under the category of green consumption, are often thought to live a green lifestyle. Green lifestyles, defined by Lorenzen, "include a collection of practices by which people today try to address an interrelated set of environmental problems: climate change and rising sea levels, air and water pollution, peak oil, and the increasing size of landfills, among others" (2012: 94). Or in more general terms, the "green lifestyle relies on meaningful practices that prioritize reducing consumption of goods, energy, and water" (Lorenzen, 2012: 97). However, researchers have defined green consumption narrowly. In their study on barriers to green consumption Gleim, Smith et al (2013) focus on what prevents consumers from purchasing green products and services. They define a green product as: "one that is produced with concern for the physical environment: air, water, and land" (Shrum, McCarty, \& Lowrey, 1995: 72). They suggest this definition "incorporates all facets of green as a marketing strategy, not just a select set of sub-components (e.g., recycling, organic purchasing, and energy consumption) and is therefore appropriate for delineating the scope of green for the present research (Shrum, et al., 1995: 45). They take into account the consumption of new products, but do not account for the consumption of used products as part of green consumption. As a result, green marketing campaigns have focused on popular acts like shopping locally, toting reusable shopping bags, driving hybrid cars, or eating green as a way to healthier living (McGrady, 2008).

This definition of green consumption does not take into account the motivations that used merchandise consumers have described for choosing used rather than a new item. A number of bloggers who write about "thrifting" in the United States and Canada state that one of their primary reasons for buying used rather than new items are concerns about the environment and sustainability (Wolk-Stanley, 2014; Hardin Turosak, 2014; Van Huizen, 2014). Katy 
Wolk-Stanley, a blogger in Portland, Oregon, who has been interviewed by the "Today Show" in 2012, explained the purpose of writing her popular blog, "The Non-Consumer Advocate," is to "help people learn to live on less, and to do so in a way that lessens their environmental impact" (Wolk-Stanley, 2014). Wolk-Stanley is dedicated to purchasing nothing new. "I have decided to challenge myself with being part of 'The Compact,' which is a movement of people all over the world who are choosing to think outside of the 'big box' and buy nothing new" she writes (2014).

Amy Hardin Turosak, a blogger from Denver, Colorado writes in her blog "The Thrifty Chicks" about her desire to promote thrift store shopping based on environmental concerns. "I wish to be a leading advocate in building a more robust repurpose and reuse market in America; similar to Michael Pollan and food security. Economists and environmentalists have yet to study the obvious advantages of this market; so little is known about the reuse economy and how it sustains the environmental and economic health of a community" she states. Turosak clearly pinpoints the issue that we explore in this article - that the re-use market has been overlooked by those studying green consumerism. Her perspectives on the importance of the reuse merchandise market have been widely covered by media outlets, such as NBC, the Mother Nature Network, Women's Day, KGNU Public Radio, and MSN Money.

Influential bloggers in Canada have expressed similar motivations. Julie Van Huizen from Hamilton, Ontario explains in her blog "We So Thrifty" that at first she shopped for used clothing because she found malls to be "gross, expensive, and soulless," but she has more recently decided "to put more effort into ethical shopping" and she adds that "also eco-friendly, social-conscious, and so much fun" (Van Huizen, 2014). While Van Huizen is not solely focused on shopping for environmental reasons, she does cite them as an overlapping concern (2014).

Another blogger from Vancouver, British Columbia who writes under the alias "Thrift Shopper for Peace" describes her motivations as mixed but also definitely as having an environmental component. "Why 'Thrift Shopper for Peace'?" she asks, "For me, thrift is more than a shopping option, it is a lifestyle. It is active peacemaking. Thrift shopping supports the environment, volunteerism in the community, charity at home and abroad. It creates a level shopping ground for people of all income levels. When I donate and purchase at a thrift shop I'm keeping things out of a land-fill - making peace with the environment" she states (2014).

Although this is a small sampling of blogs on shopping in the re-use market, they demonstrate the role that environmental concerns play in motivating consumers to shop for used items. All four of these bloggers reference environment concerns and sustainability as factors that influence their decision to shop and write about the re-use merchandise sector. This pattern suggests common motivations that are likely to be shared by other consumers of used items. The strong correlation between consumers desires to live a green lifestyle and their choice to shop for used merchandise raises questions about why this sector has been overlooked in research on green marketing.

\section{THE ABSENCE OF THE USED MERCHANDISE SECTOR IN GREEN MARKETING}

Green marketing entails the study of all efforts to consume, produce, distribute, promote, package, and reclaim products in a manner that is responsive and sensitive to ecological or environmental concerns (Dahlstrom, 2011) a definition supported through other literature on green marketing (Bonini \& Oppenheim, 2008; Ginsberg \& Bloom, 2004; Grant, 2007; Ottoman, 1998; Polonsky \& Rosenberger, 2001; Wasik, 1996). Up to this point, it has focused on human and industrial activity in relation to consumption, climate change, energy use, water, land, and biodiversity. The used merchandise sector and "second-hand shopping remains relatively unstudied even as it raises crucial issues including the repeated circulation of used objects among consumers" (Guiot \& Roux, 2010). Repeated circulation, or recycling, is paramount for consumption reduction, as it prolongs objects' useful life. However, reducing consumption and the repeated circulation of goods eliminates a substantial portion of revenues for traditional retailers (Bauhain-Roux \& Guiot, 2001). "In business, and particularly in marketing, consumption has been treated as a proxy for market demand, and more consumption has been seen as better for business (Sheth, et al., 2011: 25). Hence, consumption reduction has received very little attention in green marketing and green consumerism.

As a business goal, sustainability requires action that makes a positive impact socially, economically, and environmentally (Sheth, et al., 2011). Both industry and individuals would have to "question the negative aspects of 
over-consumption: indebtedness, waste, environmental and social costs" (McLeod, 2010: 38.2). Western society celebrates consumption, and encourages over-consumption - "acquiring things at a scale that exceeds one's needs, or even one's capacity to consume" (Sheth, et al., 2011: 28). In fact, Schor (quoted in Mooallem, 2009) concluded that by 2005 , the average U.S. consumer purchased one new article of clothing every five and a half days. According to the ecological footprint analysis, the world passed the point of sustainability in 1978 (Wackernagel et al., 2002). "Even economists, a group that has traditionally been dismissive of scientific assessments of declining natural capital, have begun to recognize that the current scale of consumption is not sustainable" (Schor, 2005: 309). "The trend of continuing rise in consumption is neither sustainable nor healthy" (Sheth, et. al., 2011: 26) and has had devastating implications on the environment and consumer debt. Yet, we continue to dismiss the implications of our desire to consume.

\section{CONCLUSION}

Green marketing and green consumption are important steps towards environmental sustainability (Sheth, et al., 2011). However, the information presented in this study suggests our focus also needs to be on consumption reduction. Consumption reduction entails prolonging a product's lifecycle. This can be accomplished through second-hand shopping at used merchandise stores. The benefits of consumption reduction and pro-environmental behaviors should be considered by the used merchandise sector as well as researchers studying green marketing. Peattie (2001) stated:

Concern about the social and environmental impacts of commerce can be traced back over thousands of years. During the last thirty years, this concern has intensified, and a major debate has sprung up about the relationship between marketing and the physical environment. Marketing has been cast as both a major villain for its role in stimulating unsustainable levels of demand and consumption, and also as a potential savior through the application of market mechanisms to tackle social and environmental problems.

Consumer efforts to purchase more products that have a lighter environmental footprint (Sheth, et al., 2011: 26) have heightened. While consumers are placing greater importance on environmentally friendly purchases, they do not always purchase green products (Gleim et al., 2013) and choose used items instead. This is a positive sign for the used merchandise sector.

Retailers in this sector still compete with conventional retailers. For example, Wal-Mart spends $\$ 500$ million annually to develop and implement green technologies (Fetterman, 2006), and GE reportedly invested $\$ 10$ billion into their green product retail line (Fast Company, 2011). However, conventional retailing techniques, such as 'green washing'- companies claiming to be environmentally friendly, but instead acting in a manner perceived to be harmful to the environment (Kangun, Carlson \& Grove, 1991) have led consumers to become hesitant about purchasing green products (Gleim, et al., 2013). Moreover, conventional retailers' marketing efforts, such as those of the Body Shop, limited to acts, such as changing the retail ambience to associate customer consumption with being an environmentally friendly organization (Polonsky \& Ottoman, 1998) are deceptive and unethical to some consumers. These consumers may choose to shop for used merchandise instead.

This is a critical moment in marketing; the media is strategically poised to shape public perceptions of green lifestyles, green consumerism, and the used merchandise sector. Based on the pressing environmental issues we face; it is critical that these concepts be promoted positively. Second-hand shopping is a relevant and rational solution to bypass conventional retailing, (Guiot \& Roux, 2010) but a solution that needs to be better communicated to the average consumer. One of the ways the used merchandise sector can deliver this solution and help manage public perception, is by sharing consumer perspectives about the value of thrifting, and living a green lifestyle through new media, such as blogs. Through this medium, consumers tell stories and present images to illustrate the value of shopping second-hand. As an outwardly focused discipline, marketing is in a strong position to address problems associated with external stakeholders (Parmar, Freeman, Harrison, Wicks, Purnell \& De Colle, 2010). Through blogs, and other mediums, marketing can illuminate the value of the used merchandise sector while addressing consumers' negative perception of conventional retail practices of "green washing" and obliviousness toward over-consumption and environmental devastation - issues that should matter to all of us. 


\section{AUTHOR BIOGRAPHIES}

Dr. Kelly La Venture is Assistant Professor of Marketing and Director of Marketing Assistance and Research Solutions, College of Business, Bemidji State University, Bemidji, MN. She teaches undergraduate courses in research, management, and marketing and MBA courses in corporate social responsibility and marketing management. She earned her doctorate from the University of St. Thomas (MN) and is co-author of The Human Factor to Profitability: Building a People-Centered Culture for Long-Term Success (Austin, TX: River Grove Books, 2015). Dr. La Venture is the contact author and may be reached at klaventure@bemidjistate.edu

Chantal Norrgard is an independent scholar based in Vancouver, British Columbia. She earned her Ph.D. from the University of Minnesota in History and is the author of Seasons of Change: Labor, Treaty Rights, and Ojibwe Nationhood (Chapel Hill: University of North Carolina Press, 2014).

\section{REFERENCES}

Alwitt, L. F. \& Pitts, R. E. 1996. Predicting purchase intentions for an environmentally sensitive product. Journal of Consumer Psychology, 5(1): 49-64.

Anonymous. 2014. Thrift shopper for peace-about.http://thriftshopperforpeace.wordpress.com/about/. Accessed 23 September 2014.

Awan, U., Sarwar, S. \& Amir Raza, M. 2011. Green consumer behavior and environmental sustainability. Journal of Science \& Technology, 1(1): 1-3.

Bauhain-Roux, D. \& Guiot, D. 2001. "Le développement du marché de l'occasion. Caractéristiques et enjeux pour le marché du neuf, Décisions Marketing, 24(sept-déc.): 25-35.

Berger, I. E. 1997. The demographics of recycling and the structure of environmental behavior. Environment and Behavior, 29: 515-31.

Berger, I. E. \& Corbin, R. M. 1992. Perceived consumer effectiveness and faith in others as moderators of environmentally responsible behaviors. Journal of Public Policy \& Marketing, 11: 79-89.

Bonini, S. \& Oppenheim, J. 2008. Cultivating the green consumer. Standford Social Inovation Review. http://www.ssireview.org. Accessed 29 August 2014.

Cross, G. 2000. An all-consuming century: Why commercialism won in modern America. New York: Columbia University Press.

Dahlstom, R. 2011. Green Marketing Management. Mason, OH: South-Western Cengage Learning.

Darley, W. K. \& Lim, J. 1999. Effects of store image and attitude toward secondhand stores on shopping frequency and distance traveled. International Journal of Retail \& Distribution Management, 27(8): 311-318.

Fast Company. 2011. For its green dreams for trains, planes, and automobiles. www.fastcompany.com. Accessed 28 August 2014.

Fetterman, W. in USA Today. 2006. Wal-mart grows 'green' strategies. http://www.usatoday.com/money/industries/retail/200609-24-wal-mart-cover-usat_x.htm. Accessed 1 September 2014.

First Research. 2014. Used merchandise stores. Industry Sales Report. http://www.hoovers.com. Accessed 9 September 2014.

Free, R. 2010. 21st century economics: A reference handbook. Thousand Oaks, CA: SAGE Publications, Inc.

Gallup. 2014. Environment. http://www.gallup.com/poll/1615/environment.aspx. Accessed 28 August 2014.

Ginsberg, J. M. \& Bloom, P. N. 2004. Choosing the right green marketing strategy. MIT Sloan Management Review, 46(1): 7984.

Gleim, M. R., Smith, J. S., Andrews, A., Cronin, J. J. 2013. Against the green: A multi-method examination of the barriers to green consumption. Journal of Retailing, 89(1): 44-61.

Grant, J. 2007. The green marketing manifesto. Hoboken, NJ: Wiley.

Guiot, D. \& Roux, D. 2008. Des vide-greniers aux ventes sur Internet: l'essor sans precedent des marches de l'occasion in L'etat des enterprises 2009, Reperes, Paris: La decouverte: 3-13.

Guiot, D. \& Roux, D. 2010. A second-hand shoppers' motivation scale: Antecedents, consequences, and implications for retailers. Journal of Retailing, 86(4): 355-371.

Hardin Turosak, Amy. 2014. Thrifty chicks-shopping golightly. https://www.blogger.com/profile/04086883816963590796. Accessed 23 September 2014.

Hoyer, W. D. \& MacInnis, D. J. 2010. Consumer Behavior 5/e, Mason, OH: South-Western Cengage Learning.

Kangun, N., Carlson, L. \& Grove, S. 1991. Environmental advertising claims: A preliminary investigation. Journal of Public Policy \& Marketing, 10(2): 47-58.

Konerding, E.F. 2010. American women during World War II: An encyclopedia. CHOICE: Current Reviews for Academic Libraries May 2010: 1669. Educators Reference Complete.

Levin, G. 1990. Consumers turning green: JWT survey. Advertising Age, 61: 74.

Lorenzen, J. A. 2012. Going green: The process of lifestyle change. Sociological Forum, 27(1):94-116. 
McGrady, V. 2008. Green up your act. Scholastic Parent \& Child, 15(6): 771.

McLeod, A. 2010. Exhibition review: The joy of shopping. History Australia Monash University Eppress, 7(2): 38.1-38.2.

Mooallem, J. 2009. The self-storage self. The New York Times Magazine, September: MM-24.

NARTS. 2014. Monthly retail trade survey. http://www.narts.org. Accessed 2 September 2014. National Retail Federation. 2014. Retail insight center: Back-to-school shopping. https://nrf.com/ Accessed 3 September 2014.

Ottman, J. A. 1998. Green marketing: Opportunity for innovation. Lincolnwood: NTC Business Books.

Paco, A., Alves, H., Shiel, C. \& Leal Filho, W. 2013. Development of a green consumer behavior model. International Journal of Consumer Studies, 37: 414-421.

Papaoikonomou, E. 2013. Sustainable lifestyles in an urban context: Towards a holistic understanding of ethical consumer behaviours. Empirical evidence from Catalonia, Spain. International Journal of Consumer Studies, 37: 181-188.

Parmar, B. L., Freeman, R. E., Harrison, J. S., Wicks, A. C., Purnell, L. \& De Colle, S. 2010. Stakeholder theory: The state of the art. Academy of Management Annals, 4(1): 403-445.

Peattie, K. 2001. Toward sustainability: The third age of green marketing. Marketing Review, 2(2): 129-146.

Peattie, K. \& Peattie, S. 2009. Social marketing: A pathway to consumption reduction? Journal of Business Research, 62: 260268.

Pieters, R., Bijmolt, T., van Raaij, F., de Kruijk, M. 1998. Consumers' attributions of proenvironmental behavior, motivation, and ability to self and others. Journal of Public Policy \& Marketing, 17: 215-225.

Polonsky, M. J. 1995. A stakeholder theory approach to designing environmental marketing strategy. Journal of Business and Industrial Marketing, 10(3): 29-46.

Polonsky, M. J. \& Ottoman, J. 1998. Stakeholders' contribution to the green new product development process. Journal of Marketing Management, 14(6): 533-557.

Polonsky, M. J. \& Rosenberger, P. J. 2001. Reevaluating green marketing: A strategic approach. Business Horizons, 44: 21-30.

Schwartz, J. \& Miller, T. 1991. The Earth's best friends. American Demographics, 13: 26-35.

Schor, J. B. 2005. Prices and quantities: Unsustainable consumption and the global economy. Ecological Economics, 55: 309320.

Sheth, J. N., Sethia, N. K. \& Srinivas, S. 2011. Mindful consumption: A customer-centric approach to sustainability. Journal of Academy of Market Science, 39: 21-39.

Shrum, L. J., McCarty, J. A. \& Lowrey, T. M. 1995. Buyer characteristics of the green consumer and their implications for advertising strategy. Journal of Advertising, 24(2): 71-82.

Statistics Canada. 2014. Canadian Industry Statistics. Used Merchandise Stores (NAICS 45331): Retail Revenues and Expenses. https://www.ic.gc.ca. Accessed 22 September 2014.

Thøgersen, J. 2011. Green shopping: For selfish reasons or the common good. American Behavioral Scientist, 55(8): 1052-1076.

Tucker, J. \& Ryan, J. 2013. Economics with emphasis on a free enterprise system. Mason, OH: South-Western/Cengage Learning.

United Nations. 1987. Report of the world commission on environment and development: Our common future. http://conspect.nl/pdf/Our_Common_Future-Brundtland_Report_1987.pdf. Accessed 7 August 2014.

Van Huizen, J. 2014. What's this all about? http://wesothrifty.com/about/. Accessed 23 September 2014.

Vandermerwe, S. \& Oliff, M. 1990. Customers drive corporations green. Long Range Plan, 23(6): 10-6.

Wackernagel, M., Schulz, N. B., Deumling, D., Callejas Linares, A., Jenkins, M., Kapos, V., Monfreda, C., Loh, J. Myers, N., Norgaard, R. \& Randers, J. 2002. Tracking the ecological overshoot of the human economy. Proceedings of the National Academy of Sciences, 99(14): 9266-9271.

Wasik, J. F. 1996. Green marketing and management: A global perspective. Cambridge: Blackwell Business.

Williams, C. C. \& Paddock, C. 2003. The meanings of informal and second-hand retail channels: Some evidence from Leicester. International Review of Retail, Distribution and Consumer Research, 13(5): 317-336.

Wolk-Stanley, Katy. 2014. About-the non-consumer advocate. http://thenonconsumeradvocate.com/aboutkaty/. Accessed 23 September 2014.

Worcester, R. 1993. Public and elite attitudes to environmental issues. London: MORI. 


\section{NOTES}

